\title{
Research on the Effectiveness of College Students' Ideological and Political Education Based on Mobile Internet
}

\author{
Chao Wang ${ }^{1, a}$ and Junzheng Wang ${ }^{1, b^{*}}$ \\ ${ }^{1}$ Xincheng Street 2888, Jilin Agricultural University, Changchun, Jilin Province 130118, PR China \\ a29251275@qq.com, $595845966 @ q q . c o m$ \\ ${ }^{*}$ The corresponding author
}

Keywords: College students; Mobile internet; Effectiveness; Ideological and political education

\begin{abstract}
Ideological and political education is an essential part of the process of human survival and development, which has the characteristics of times, class and politics. As an important part of college education, which has been attracted much attention. The ideological and political education methods are not unchangeable, but with the development of the times, they need to be innovated continuously. The mobile Internet has gradually entered people's life and has brought new challenges to the ideological and political education of college students, educators should propose new measures of keeping pace with the times to improve the effectiveness of ideological and political education.
\end{abstract}

\section{Introduction}

The main network terminals of mobile Internet are not computers but mobile phones. According to data, up to December 2015, the size of China's mobile phone users reached 620 million, $90.1 \%$ of Internet users through the mobile phones. The number of net citizens who only use mobile phones to surf the Internet reached 127 million, accounting for $18.5 \%$ of the whole Internet users. Mobile Internet has been accepted by the massive people for its quickness and convenience, college students is also deeply affected. The ideological and political education plays an important role in our country's higher education, college educators are responsible for the ideological and political education of college students. Therefore, educational officers working in universities should transform their educational concepts first, they should follow the development of times, realize that mobile Internet is a"double-edged sword" generally, and combine the advantages of Internet. Most importantly, they should create new approaches of ideological and political education positively.

\section{The Characteristics of the Mobile Internet}

Convenience. Compared with the PC Internet, the biggest advantage of mobile Internet is convenience. Its main terminal representatives are mobile phones and tablet computers, these items are so small that they are very easy to carry. Intelligent mobile phones only need to connect to the network, and then students can search the desired content anywhere and anytime. Because of their timely, convenient and cheap, intelligent mobile phones are very popular with college students. At present, almost each student has a mobile phone, college educators can make good use of the advantage and carry out the ideological and political education tocollege students in a timely and effective manner.

Timeliness. Compared with the traditional way of receiving information, the timeliness of mobile Internet is the main driving force for its rapid development. Now, all kinds of softwares have been developed, students only need to carry the mobile terminal and can quickly obtain the disseminative information. In the information age, obtaining information in time and processing information are also new ways to survive. For most college students, their time is very precious, the mobile Internet also provides immense conveniences for them in study and life aspects, such as acquire knowledge.

Richness. The information on the Internet is almost all-inclusive, from the past to the present, 
from home to abroad and form astronomy to geography, it can be said that only you can not think out, no information you can not search out. However, it should be noted that the mobile Internet is a "double-edged sword", it can also spread bad information. College students now are incapable of resisting the temptation of bad information, then the university educators must carry out ideological and political education, if necessary, they can also take some supervisory measures.

Fusion. The mobileInternet is different from thesingle traditional way of spreading information, it hasenriched the information disseminative way whichunites text, picture and other forms of static transmissionto a dynamic manner to spread out information. It has improved acceptability of information dissemination, therefore, students are more willing to know information and the way is not easy to cause aesthetic fatigue and visual fatigue.

\section{The Influence of the Mobile Internet Brings to the Ideological and Political Education}

Positive Impact. (1) To Improve the Comprehensive Quality of Ideological and Political Educators. Ideological and political educators play a leading role in the whole process of education and control the effect of the education process, so the quality of college educators is crucial, which is directly related to the success of ideological and political education. With the continuous development of mobile Internet technology, educators' educational concepts, methods of educators cannot detain in the past. They need to learn to innovate. In the mobile Internet environment, educators can obtain information, learn new knowledge and broaden their horizons at anytime and anywhere, they can also communicate with experts all over the world, solve puzzles and determine the key points and contents of their works, which gradually improve their teaching level.

(2) To increase the Effectiveness of the Ideological and Political Education. Firstly, the mobile Internet has enriched the learning resources, traditional ideological and political education content is limited to textbooks, newspapers, radio and so on, its content is obsolete and cannot be updated in a timely manner, and other shortcomings such as slow propagation. While the mobile Internet has many features including abundant resources, various types of information, convenient communication and so on, so all kinds of information dissemination forms such as pictures, text, video, audio and so on cannot be limited by time and space, college students can look up at any time, which provides convenience for the dissemination of information. College educators can use these advantages to update the teaching resources and add to new teaching contents, they also can understand the latest cases to analyse and explan to college students, which can achieve good teaching effect. Mobile Internet also provides a new educational way, the way in traditional classroom is a kind of passive form to impart knowledge and its content is monotonous which most students are not interested in, most of the students are too shy to say their true ideological problems in front of other students, which leads to bad effect of Ideological and political education. The Internet provides an anonymous environment which canexpress opinions freely, college students would like to express their real ideas, from international situation, national affairs to emotinal trivias and anecdotes. As long as they have the same feeling, students always would like gather together in the network to express their views. Mobile Internet can provide a virtual environment for teachers and students, students can anonymously put forward their own problems and then educators can give some reasonable advice to help them to solve theirs problems, which helps educators understanding the new and real thoughts of college students and improving the effectiveness of Ideological and political education.

(3) To Provide New Learning Methods for College Students. College students acquire knowledge in traditional way is through textbooks and query data only through the books in the library. In most cases, students could not borrow the books they want and their learning efficiency has reduced, because the library books are limited and the number of students is large. The emergence of the mobile Internet just solves the problem, on the Internet, students not only can download the electronicbooks, but also can obtain information about professional information in timesuch as teaching scientific research, academic trends and so on. Through the Internet, students can stay at home and understand the domestic and international events to widen the knowledge of college students. College educators can also use this advantage to combine the content of 
Ideological and political education to network, which can save a lot of valuable time of college students.

(4) To Enrich College Students' Extracurricular Life. When students need to wait in any time such as queuing up for a meal, waiting for the bus and so on, they can kill time by browsing news, listening to music and watch movies via mobile phone, rather than suffering waiting. College students in their spare time can buy some favorite items through online store, convey sorrows or share life through micro-blog and WeChat and cultivate their taste through electronic books and watching movies. These make college students' extracurricular life more colorful.

\section{Negative Impact}

(1) Brings Some Challenges to the Ideological and Political Educationors. The mobile Internet has the characteristics of open and convenience, so many college students can immediately to check all kinds of public or internal, true or false information by their accompanied mobile phones, rather than easily accepting blind indoctrination of the traditional ideological and political educators. If the imparting content of teachers is not fully convincing or lacks of sensitivity to the novelty, students will suspectthe imparting knowledge of teachers, which will affectthe authority of teachers. In the practical teaching process, educators need to broaden their knowledge continually and help students to identify the authenticity of the information to aviod students detouring and falling into a wrong path.

(2) Bring Adverse Impact on College Students' Study and Life. With the continuous development of mobile network technology, a variety of mobile games were developed, many college students are addicted to games, unable to control his playing time and even don't go to class, resulting in wasting their studies, therefore they fail in the exams in many subjects and cannot get a diploma. Some students have poor health because of staying up late to play games. With the popularization of mobile phone, many criminals spread bad information through Internet, college students are lack of ability to distinguish right from wrong and cannot resist the temptation, then damaging their physical and mental health. The mobile Internet also changes the interpersonal relationships of college students, it can provide virtual environment, students can be cynical and say what they want to say, so they are more willing to live in virtual network environmentand ignore the relationship in real life. Many criminals use the Internet to spread false information, college students thinking is simple, so it is easy for them to be deceived.

\section{The New Methods Based on the Mobile Internetto Improve the Effectiveness of Ideological and Political Education in Colleges}

Educational Workers Should Change Their Educational Ideas and Create New Educational Ways. The important principle of Ideological and political education in Colleges is to keep pace with the times. The emergence of the mobile Internet, the educational environment has changed, firstly educators should change the concept of education, take the initiative to understand the characteristics of the mobile Internet and recognize the changes bringing about by the mobile internet. The traditional classroom education, educators play a leading role, they will teach students after sorting out the content, which is a kind of passive form to impart knowledge. Students select knowledge to absorb according to their own interest, the effect of education is very poor. In the context of mobile Internet, because of students' learning autonomy and the impact of the equality of the network and so on, the authority of the educational workers is challenged, the traditional way of education has not been able to adapt to the learning needs of college students. At this time, educators need to change the educational concept and come up with new ways of education. They can pay close attention to the issues that college Students are interested in, analyze these issues deeply in class and give students some inspiration to arouse their sympathy, so as to make students convince the content of Ideological and political education. Education workers also need to grasp new knowledge in order to correctly guide the students and give reasonable suggestions. 
Build a New Platform for Ideological and Political Education of College Students. With the rapid development of mobile Internet technology, the ideological and political education means of college students are more and more modern. College education workers should keep pace with the times, actively open up the Internet position and innovate effective means of education continuously. Educators can use mobile technology to create the WeChat public number, micro-blog and so on to push theory and cases and promote the ideological and political education of college students positively. At present, almost every grade, each class or each group has its own QQ group and WeChat group, counselors can communicate with the students through the QQ group and WeChat group and can also through circle of friends and QQ space, understand the student's ideaistic dynamic. The platform and form of work are the foundation of completing the task of Ideological and political education successfully, so it is very important to construct a new platform for the ideological and political education of college students.

Improve the Management and Monitoring of Mobile Internet. Mobile Internet technology is a double-edged sword, the college students can get useful information through the Internet and also will be affected by some bad information. Facing the bad information, it is difficult for college students to resist the temptation, so it is very necessary to strengthen the monitoring of the network. The ideological and political education workers can start from the following aspects, when students browse the website information, they can set up some safety tips to remind students of shielding bad information and can also set up mobile network management team, using various methods to improve comprehensive supervision of network public opinion.

To Strengthen the Subject Education for College Students. Moral education is a fundamental goal of higher education, ideological and political education purpose and the ultimate aim are to cultivate people who are all-round development of high quality and outstanding talents of socialist construction. College educators should be based on the ideological characteristics of college students to carry out the subject education, which makes students establish correct ideas, learn the proper use of the mobile Internet and enhance the quality, so as to improve the effectiveness and pertinence of Ideological and political education.

\section{Conclusion}

All in all, in the mobile Internet environment, the ideological and political education should face to the world, the modernization and follow by the pace of Internet technological development to innovate effective education methods. Education workers must guide students to identify the authenticity of the network information, students should select to absorb network information, cannot blindly believe the network information, establish the correct ideological concept and regulate the use of the internet. The mobile Internet has broadened the ideological and political education platform, after educational work in the classroom, educators should make full use of the mobile Internet platform to improve the effectiveness of Ideological and Political Education.

\section{Acknowledgements}

Project: Students work research branch of China's higher education institute "in 2016 university students work study general subjects: higher school counselor team construction of specialized research" (project approval number: LX2016Y013)

\section{References}

[1] CNNIC. 37 times China Internet network development state statistic report [J]. China Internet network information center, 2016 (1).

[2] Zhang Qing. The authority of teachers role in network education and social reasons of the changes in the $[\mathrm{J}]$. Journal of hunan normal university education science, 2010, 25 (5): 106-108. 
[3] Long Shiping Luo Dinghua. Mobile Internet era of ideological and political education of thinking [J]. Journal of news front. 2014 (6) : 143-144

[4] Huang Mingwei. College students' network ideological and political education implementation elements research [M]. Beijing: xinhua publishing house, 2007.

[5] Zhao Xiaoping. Mobile Internet era of ideological and political education effectiveness research [J]. Journal of vocational education (late), 2014, (4): 58-61.

[6] Du Liang. Based on the $3 \mathrm{~g}$ era of mobile Internet ideological and political education innovation strategy [J]. Journal of counselors work research, 2010, (1): 82-86.

[7] Xu Zhenxiang. New media: opportunities and challenges of ideological and political education [J]. Journal of ideological and political education research, 2007 (6).

[8] Zhao Ming. Thinking about enhancing education courses in colleges and universities teaching effectiveness [J]. Journal of jilin institute of education, science, 2010 (10).

[9] Liu Yu. Mobile media horizon, mobile education management analysis for college students' ideological and political education work, for example [J]. Journal of henan academy of social sciences, 2012 (11): 52.

[10] Xu Chang. Mobile Internet influence on ideological and political education and countermeasures [J]. Journal of xianning college, 2011, 22 (5): 59-61. 